\title{
Analyses of Metals Impact on Humulus lupulus Strobili Antioxidant Capacity
}

\author{
DUŠAN Đ. PAUNOVIĆ1 ${ }^{1}$ SNEŽANA S. MITIĆ2 (Dhttps://orcid.org/0000-0003-3301-5981), \\ IVANA D. RAŠIĆ MIŠIĆ ${ }^{2 *}$ (iD https://orcid.org/0000-0003-4825-6980), \\ MILAN N. MITIĆ2 (D https://orcid.org/0000-0002-1310-0540), \\ ALEKSANDRA N. PAVLOVIĆ ${ }^{2}$ (iDhttps://orcid.org/0000-0003-2053-3106), \\ GORDANA M. KOCIĆ ${ }^{\mathbf{3}}$ (' https://orcid.org/0000-0003-2386-2466) \\ ${ }^{1}$ University of Union Nikola Tesla, Faculty of Applied Science, Department of Contemporary Food Technology, Niš, \\ Serbia \\ ${ }^{2}$ University of Niš, Faculty of Sciences and Mathematics, Department of Chemistry, Niš, Serbia \\ ${ }^{3}$ University of Niš, Faculty of Medicine Niš, Niš, Serbia
}

\begin{abstract}
This paper presents results of analyses of metal ions effects on hop strobili antioxidant characteristics. Determination of total phenols (TP), total flavonoids (TF) and fifteen phenolic compounds, as well as the antioxidant activity (DPPH, ABTS and FRAP) of hop extracts from eight samples was conducted using UV/Vis spectrophotometry and HPLC method. Contents of 24 elements in mineralized hop samples were determined by ICP-OES. Very strong negative relationship between $T P, T F$, antioxidant capacity results and $\mathrm{Pb}, \mathrm{Co}, \mathrm{Cr}, \mathrm{Sb}$ and $\mathrm{Na}$ was determined applying principal component and cluster analyses. Namely, the higher concentrations of these metals were associated with lower contents of TP and TF and lower values of antioxidant tests. Impact of metal ions on phenolic and flavonoids content and antioxidant activity of hop strobili has not been previously published.
\end{abstract}

Keywords: hop; phenolic compounds; antioxidant capacity; metal ions; statistical analyses

\section{Introduction}

Hop (Humulus lupulus $L$ ) is a plant widely known for its usage in brewing industry, precisely in beer production. All parts of this plant are a source of polyphenolic compounds such as flavonoids, catechins, flavanones, phenolic acids, etc. Phenolic compounds or polyphenols are a wide group of plant metabolites and represent nonessential dietary components. Antioxidant action of plant extract is usually related to the presence of these compounds [1]. Large number of studies shows that among all phenolic compounds, flavonoids are of the greatest significance for antioxidant activity of plant. Hydroxyl groups, especially their position, play an important role for antioxidant activity of flavonoids, since they are responsible for donating hydrogen atom and thus scavenge free radicals [2, 3]. According to biological importance (antioxidant activity above all), phenolic compounds with two or three vicinal hydroxyl groups at C-atoms of benzene rings especially protrude as stated by Heim et al. [3] and Rice-Evans et al. [4, 5]. One of the most important properties of these compounds is that they get easily oxidized by molecular oxygen under physiological conditions. In these autooxidation reactions, semiquinones, quinones and reactive oxygen species (ROS) are produced.

Metals are omnipresent in various biological systems. The uptake of metals, both by roots and leaves of plants, increases with metal concentration in external medium. Shah et al. reported that $\mathrm{Cd}$, $\mathrm{Cr}, \mathrm{Pb}, \mathrm{As}, \mathrm{Sb}$ and $\mathrm{Hg}$ are toxic for plants [6]. They can inhibit electron transport, reduction of $\mathrm{CO}_{2}$ fixation and affect plant growth through generation of free radicals and reactive oxygen species. However, plants use complex processes which activate the cells to adopt their metabolism to metal stress. Some heavy metals are essential for biological and physiological functions of plants, however, these metals become toxic depending on the nature and species of metal and plants. As stated by Lechno et al., Hernandez and Almansa, sodium ions can also be toxic for some plants [7, 8].

\footnotetext{
*email:ivana.rasic@pmf.edu.rs
} 
The ability of metals to interact with polyhydroxy phenols during their transformation was investigated under different experimental conditions [9-13]. Recently, a few papers have been published that solely documented the metal content of hop and conveyed geographical characterization of hop origin based on their elemental plant and soil content [14, 15]. Lately, Liu et al. presented identification of geographical origin of this plant done by multi-metal elements fingerprinting along with the relationships with functional ingredients [16]. Few other studies focused exclusively on antioxidant activity of hop' extracts [17-24]. The impact of metal content (especially toxic metals) and antioxidant activity of hop strobili has not been analyzed by these authors.

Because of all above mentioned, the aim of this paper was to analyze metals content effect on antioxidant activity of hop strobili. In order to obtain this relationship, it was necessary to determine total phenols (TP) and total flavonoids (TF) in hop strobili, as well as their antioxidant activity (DPPH, ABTS and FRAP) and metal content. Various individual phenolic compounds were also quantified.

\section{Materials and methods \\ 2.1.Plant material}

Strobili of eight hop samples were purchased at local markets. Each paper-aluminium bag contained $500 \mathrm{~g}$ of hop. Five bags of each sample were bought and mixed. In order to prepare samples for analysis, 2 grams from each mixed sample were taken in triplicate for each preparation method and further analyzed. Samples were stored in polyethylene bottles upon preparation.

\subsection{Chemicals}

The following certification standards were used: gallic acid (Carl Roth, Karlsruhe, Germany), quercetin-3-rutinoside, quercetin-glucoside, kaempferol-glucoside, p-coumaric acid, chloregenic acid (Merck, Darmstadt, Germany) and quercetin-galactoside (Extrasynthese, Genay, France), 4hydroxybenzoic acid, ferulic acid, (+)-catechin and (-)-epicatechin (Sigma Aldrich, Steineheim, Germany). Kaempferol-glucoside was used as the equivalent for kaempferol-rutinoside and quercetin3-glucoside was used as the equivalent for quercetin-glycoside. The ICP multi-element standard solution of $20.00 \pm 0.10 \mathrm{mg} / \mathrm{L}$ (Ultra - scientific (North Kingstown, RI, U.S.A.) was used as a stock solution for calibration. The following reagents were also used: 1,1-diphenyl-2-picrylhydrazyl radical (DPPH), 2,2'-azinobis(3-ethylbenzothiazoline-6-sulfonic acid) (ABTS), potassium peroxydisulfate, ethanol (96\% by vol.), methanol (HPLC grade), acetic acid, formic acid and acetonitrile (HPLC grade) (J. T. Baker, Deventer, Netherlands). 6-hydroxy-2,5,7,8-tetramethylchroman-2-carboxylic acid (Trolox), 2,4,6-tri(2-pyridyl)-S-triazine (TPTZ) was purchased from Acros Organics, Geel, Belgium. Folin Ciocalteu's phenol reagent, iron(III) chloride, sodium hydroxide, sodium acetate, sodium nitrite, sodium carbonate, aluminium chloride hexahydrate, iron(II) sulfate heptahydrate, hydrochloric and nitric acid were purchased from Merck, Darmstadt, Germany, argon 5.0 (99.999\% purity). All chemicals and solvents were analytical grade, unless indicated otherwise.

Polyethylene bottles had been previously cleaned using 20\% nitric acid and washed with ultra-pure water $(0.05 \mu \mathrm{S} / \mathrm{cm}$ specific conductivity) in order to avoid contamination. All the glassware used was cleaned in the ethanol $\mathrm{KOH}$ solution, aqueous solution of $\mathrm{HCl}(1: 1)$ and then thoroughly rinsed with tap, distilled and finally with ultra-pure water.

\subsection{Instruments}

The recording of spectra and absorbance readings were done using Agilent $8453 \mathrm{UV} / \mathrm{Vis}$ spectrophotometer, with $1 \mathrm{~cm}$ optical path quartz cuvettes. The $\mathrm{pH}$ measurements were carried out using Hanna Instruments pH-meter with glass electrode. The model 1200 Agilent Technologies, with analytical column $\mathrm{C}_{18}$ (Zorbax Eclipse XDB-C18, $5 \mu \mathrm{m}, 4.6 \times 150 \mathrm{~mm}$ ), was used for performing HPLC analysis. Muffle furnace VIMS Serbia equipped with microprocessor temperature program IVIGOS3123 $\left( \pm 1{ }^{\circ} \mathrm{C}\right)$ was used for dry mineralization. Inductively coupled plasma optical emission spectrometer iCAP 6000 (Thermo Scientific Inc., Cambridge, UK) was applied for multielement 
analysis. This instrument uses glass concentric nebulizer, an Echelle optical design (52.91 grooves/ $\mathrm{mm}, 63.5^{\circ}$ blaze angle) and a charge injection device solid-state detector (RACID86). High precision variable volume micropipettes $\left(\mathrm{Lab}_{\mathrm{Mate}}^{+}\right.$) were used for pipetting the solutions. Ultra-pure water was obtained using MicroMed high purity water system, TKA Wasseraufbereitungssystem GmbH. Thermo-stating of refrigerated solutions and extracts was done in Julabo MP 5A Open Bath Circulations.

\subsection{Sample preparation}

Two methods were applied for the sample's preparation: extraction-maceration (for UV/vis and HPLC methods) and dry mineralization (for ICP-OES method).

Extraction of sample $(2 \mathrm{~g})$ was performed with $60 \mathrm{~mL}$ of solvent (ethanol/water, 30/70, v/v \%) during $2 \mathrm{~h}$ at $\mathrm{t}=25^{\circ} \mathrm{C}$. Suspension was filtered through Büchner funnel and Whatman No. 1 filter paper. Extracts were stored in polyethylene bottles and refrigerated till they were analyzed. The procedure was based upon methods reported by Iacopini et al. [25], Borowska et al. [26] and Katalinić et al. [27].

Dry mineralization of sample $(2 \mathrm{~g})$ was done in porcelain crucible in the electrical furnace at the increasing temperature interval from 50 to $450^{\circ} \mathrm{C}$ during the first $8 \mathrm{~h}$, after it was held constant for the next $12 \mathrm{~h}$. Cold ash-sample was dissolved in $2.5 \mathrm{~mL} \mathrm{HNO}_{3}(1: 1 \mathrm{v} / \mathrm{v})$, filtered (filter paper Whatman, 6 $\mu \mathrm{m}$ pore size) and filled with deionized water to $50 \mathrm{~mL}$. The procedure was done according to the method by Radojević and Bashkin [28].

\subsection{Spectrophotometric analysis}

\subsubsection{TP content determination}

Sample extract volume of $0.1 \mathrm{~mL}$ was transferred into the $10 \mathrm{~mL}$ volumetric flask; after that it was added $2.5 \mathrm{~mL}$ of deionized (DI) water, $0.5 \mathrm{~mL}$ of Folin-Ciocalteu reagent solution, $2 \mathrm{~mL}$ of $20 \%$ $\mathrm{Na}_{2} \mathrm{CO}_{3}$ solution and filled with water to the mark. TP content was determined by measuring absorbance at $\lambda=760 \mathrm{~nm}$ after $2 \mathrm{~h}$ against water as a blank [29,30]. The measurements were compared to the calibration line obtained using gallic acid (GA) standard solution and the results of TP content were expressed as milligrams of gallic acid equivalents (GAE) per grams of hop (mg GAE/g $\pm \mathrm{SD}$ ). The stated procedure was repeated in triplicates for each sample.

\subsubsection{TF content determination}

Reaction solution was prepared by mixing $0.5 \mathrm{~mL}$ of hop extract, $3 \mathrm{~mL}$ of DI water and $0.3 \mathrm{~mL}$ of $5 \% \mathrm{NaNO}_{2}$ according to the method by Zhishen et al. [31]. After incubation at room temperature for 5 min, $3 \mathrm{~mL}$ of $1 \% \mathrm{AlCl}_{3}$ was added. The mixture was left at room temperature for next 5 min, then 2 $\mathrm{mL} \mathrm{NaOH}(1 \mathrm{~mol} / \mathrm{L})$ and water to the $10 \mathrm{~mL}$ were added. Absorbance was measured at $\lambda=510 \mathrm{~nm}$ against water as a blank. According to the measured absorbance, the content of TF was determined using catechin calibration line and displayed as milligrams of catechin equivalent per $\mathrm{g}$ of hop (mg $\mathrm{CE} / \mathrm{g} \pm \mathrm{SD})$. The stated procedure was repeated in triplicates for each sample.

\subsection{Antioxidant activity determination}

Antioxidant activity of hop extracts was evaluated applying three independent in vitro assays: DPPH, ABTS and FRAP.

The method by Brand-Williams et al., conducted with slight modifications, was used for DPPH assay [32]. The solution of DPPH radical $\left(1 \times 10^{-4} \mathrm{~mol} / \mathrm{L}\right)$ was prepared in methanol. Initially, $5.0 \mathrm{~mL}$ of this solution and $0.1 \mathrm{~mL}$ of hop extract were mixed in $10 \mathrm{~mL}$ volumetric flask. Methanol was added to the mark. The discoloration of this radical was recorded by absorbance measurement at $520 \mathrm{~nm}, 30$ min after the beginning of the reaction against methanol as a blank. Total antioxidant activity $(\mu \mathrm{mol} / \mathrm{L})$ was determined using Trolox calibration curve. It was plotted as a function of the absorbance decrease $\left(\triangle A=A_{\text {blank }}-A_{\text {sample }}\right)$ of DPPH radical scavenging activity and the results were expressed as 
micromoles of Trolox equivalent (TE) per g of hop $(\mu \mathrm{mol} \mathrm{TE} / \mathrm{g} \pm \mathrm{SD})$. The stated procedure was repeated in triplicates for each sample.

The assay of ABTS radical cation scavenging activity was performed according to the method described by Re et al. [33] and Arts et al. [34] with slight modifications [35]. ABTS was dissolved in methanol to the concentration of $7 \times 10^{-3} \mathrm{~mol} / \mathrm{L}$. ABTS radical cation was produced by reacting ABTS stock solution with $2.4 \times 10^{-3} \mathrm{~mol} / \mathrm{L} \mathrm{K}_{2} \mathrm{~S}_{2} \mathrm{O}_{8}$ and allowing the mixture to stand in the dark at room temperature 12-16 $\mathrm{h}$ prior use. ABTS radical cation solution was diluted with methanol to obtain the absorbance of $0.7 \pm 0.02$ at $734 \mathrm{~nm}$. An aliquot of each hop extract $(0.1 \mathrm{~mL})$ was mixed with $3.9 \mathrm{~mL}$ of diluted ABTS radical cation solution. The reduction in absorbance at $734 \mathrm{~nm}$ was measured after the reaction time of $6 \mathrm{~min}$ at room temperature. The Trolox calibration curve was plotted as a function of the decrease in absorbance $\left(\Delta A=A_{\text {blank }}-A_{\text {sample }}\right)$ of ABTS radical cation scavenging activity. The results were expressed as micromoles of Trolox equivalents (TE) per gram of hop ( $\mu \mathrm{mol} \mathrm{TE} / \mathrm{g} \pm \mathrm{SD}$ ). The stated procedure was repeated in triplicates for each sample.

FRAP working reagent was prepared daily by mixing following constituents: $25 \mathrm{~mL}$ of acetic buffer $(0.3 \mathrm{~mol} / \mathrm{L}, p \mathrm{H}=3.6), 2.5 \mathrm{~mL}$ of TPTZ $(10 \mathrm{mmol} / \mathrm{L})$ in $40 \mathrm{mmol} / \mathrm{L} \mathrm{HCl}$ and $2.5 \mathrm{~mL}$ of $\mathrm{FeCl}_{3}(20$ $\mathrm{mmol} / \mathrm{L}$ ). The reaction mixture was prepared in a $10 \mathrm{~mL}$ volumetric flask with $1 \mathrm{~mL}$ of hop extract, $2.1 \mathrm{~mL}$ of FRAP reagent and water to the mark. After the incubation time of $5 \mathrm{~min}$ at $37{ }^{\circ} \mathrm{C}$, the absorbance at $595 \mathrm{~nm}$ was measured. The concentration $(\mu \mathrm{mol} / \mathrm{L})$ of $\mathrm{Fe}^{2+}$ equivalents was determined directly from the calibration curve. The final FRAP results were presented as micromoles of $\mathrm{Fe}^{2+}$ equivalents per $\mathrm{g}$ of hop ( $\mu \mathrm{mol} \mathrm{Fe} / \mathrm{g} \pm \mathrm{SD}$ ). This assay was performed according to the method given by Benzie and Strain [35]. The stated procedure was repeated in triplicates for each sample.

\subsection{HPLC analysis}

Separation and identification of individual phenolic components are of importance in order to give information about real differences in phenolic profiles of studied hop samples. Chromatographic analyses of hop extracts was carried out using the gradient procedure with the mobile phase containing solvent A (5\% formic acid in water) and solvent B (80\% acetonitrile $+5 \%$ formic acid in water) as follows: $0-28 \mathrm{~min}, 0 \% \mathrm{~B} ; 28-35 \mathrm{~min}, 25 \% \mathrm{~B} ; 35-40 \mathrm{~min}, 50 \% \mathrm{~B} ; 40-45 \mathrm{~min}, 80 \% \mathrm{~B}$ and for the last 10 min, $0 \% \mathrm{~B}$. The temperature of column was set at $30{ }^{\circ} \mathrm{C}$. The solvent flow rate was $0.8 \mathrm{~mL} / \mathrm{min}$ and the injection volume was $5 \mu \mathrm{L}$. HPLC chromatograms were recorded at 360 and $320 \mathrm{~nm}$, as well as using fluorescence detector $\left(\lambda_{\mathrm{ex}} / \lambda_{\mathrm{em}}=275 / 322 \mathrm{~nm}\right)$. The identification of individual phenolic components was performed by comparing their retention times and spectral data with those of standards. Quantification of each phenolic compound was done using external standard method. Results were expressed as mg per $\mathrm{g}$ of hop.

\subsection{ICP-OES analysis}

The operating conditions for conducting ICP-OES analysis were: power of RF generator-1150 W, pump speed - $50 \mathrm{rpm}$, flush pump speed $-100 \mathrm{rpm}$, cooling gas flow $-12 \mathrm{~L} / \mathrm{min}$, nebulizer gas flow $0.7 \mathrm{~L} / \mathrm{min}$, auxiliary gas flow $-0.5 \mathrm{~L} / \mathrm{min}$. The direction of plasma observation was dual.

\subsection{Calibration parameters}

The calibration line was plotted for each analyzed element. Linearity was considered satisfactory if the correlation coefficient (r) exceeded 0.9990, except for Al, Ca, Fe, K and $\mathrm{Mg}$ ( $\mathrm{r}<0.9990)$.

Selection of emission line in both axial and radial plasma viewing modes of each element was done based on the absence of spectral interferences and adequate sensitivity for determining low and high elements concentrations. Detection (LOD) and quantification (LOQ) limits were calculated using the following equations (1 and 2):

$$
\begin{aligned}
& \mathrm{LOD}=3.3 \times \sigma / s \\
& \mathrm{LOQ}=10 \times \sigma / s
\end{aligned}
$$


were $\sigma$ is residual standard deviation of the regression line and $s$ is a slope of calibration curve [36, 37]. Both limits were expressed in $\mu \mathrm{g} / \mathrm{g}$. The selected wavelengths, correlation coefficients (r), detection limits (LOD) and limits of quantification (LOQ) were listed in Table 1.

Table 1. Emission wavelength, LOD, LOQ

and correlation coefficient of the calibration curves for each element determination

\begin{tabular}{ccccc}
\hline \multirow{2}{*}{ Element } & \multicolumn{3}{c}{ Parameter } \\
\cline { 2 - 5 } $\mathrm{Al}$ & $\lambda(\mathrm{nm})$ & LOD $(\mu \mathrm{g} / \mathrm{g})$ & LOQ $(\mu \mathrm{g} / \mathrm{g})$ & Correlation coefficient \\
$\mathrm{As}$ & 189.042 & 0.1125 & 0.3713 & 0.9841 \\
$\mathrm{Ba}$ & 455.403 & 0.0013 & 0.2145 & 0.9997 \\
$\mathrm{Ca}$ & 393.366 & 0.0033 & 0.0043 & 0.9999 \\
$\mathrm{Cd}$ & 228.802 & 0.0048 & 0.0158 & 0.9901 \\
$\mathrm{Co}$ & 238.892 & 0.0221 & 0.0729 & 0.9999 \\
$\mathrm{Cr}$ & 283.563 & 0.0556 & 0.1835 & 0.9999 \\
$\mathrm{Cu}$ & 324.754 & 0.0149 & 0.0492 & 0.9997 \\
$\mathrm{Fe}$ & 259.940 & 0.0149 & 0.0492 & 1 \\
$\mathrm{~K}$ & 766.490 & 0.0438 & 0.1445 & 0.9957 \\
$\mathrm{Li}$ & 670.784 & 0.0015 & 0.0049 & 0.9979 \\
$\mathrm{Mg}$ & 279.553 & 0.0005 & 0.0017 & 0.9998 \\
$\mathrm{Mn}$ & 257.610 & 0.0026 & 0.0087 & 0.9985 \\
$\mathrm{Mo}$ & 202.030 & 0.0164 & 0.0541 & 0.9999 \\
$\mathrm{Na}$ & 588.995 & 0.0020 & 0.0660 & 0.9999 \\
$\mathrm{Ni}$ & 231.406 & 0.0134 & 0.0442 & 1 \\
$\mathrm{~Pb}$ & 220.353 & 0.0629 & 0.2076 & 0.9999 \\
$\mathrm{Sb}$ & 217.581 & 0.0740 & 0.2442 & 0.9999 \\
$\mathrm{Se}$ & 196.090 & 0.0707 & 0.2331 & 1 \\
$\mathrm{Si}$ & 251.611 & 0.0133 & 0.0439 & 0.9993 \\
$\mathrm{Sn}$ & 189.989 & 0.0137 & 0.0452 & 0.9993 \\
$\mathrm{Sr}$ & 407.771 & 0.0005 & 0.0016 & 0.9999 \\
$\mathrm{~V}$ & 309.311 & 0.0179 & 0.0591 & 0.9995 \\
$\mathrm{Zn}$ & 213.856 & 0.0003 & 0.0010 & 1 \\
\hline & & & & 0.9998 \\
\hline
\end{tabular}

\subsection{Statistical analysis}

The aim of statistical analyses was to find correlations between the content of TP, TF, antioxidant capacity and mineral content in hop strobili samples. Principal component analysis was used to evaluate datasets and to establish the relationship among variables. Cluster analysis was performed in order to group samples based on their proximity. Analyses were performed using a statistical package Statistica 8.0. StatSoft, Inc., Tulsa, OK, USA. A probability of $\mathrm{p}<0.05$ was considered statistically significant [36].

\section{Results and discussions}

\subsection{TP, TF content and antioxidant activity of hop extracts}

The spectrophotometric results of TP, TF content and antioxidant activity of hop were presented in Table 2.

Table 2. TP and TF content and antioxidant activity of hop

\begin{tabular}{lllllll}
\hline \multirow{2}{*}{ Sample } & \multicolumn{1}{l}{ Parameter } & \multicolumn{5}{l}{} \\
\cline { 2 - 7 } & $\begin{array}{l}\text { TP } \\
\mathrm{mg} \mathrm{GAE} / \mathrm{g}\end{array}$ & $\begin{array}{l}\text { TF } \\
\mathrm{mg} \text { CE/g }\end{array}$ & TF/TP & $\begin{array}{l}\text { DPPH } \\
\mu \mathrm{mol} \mathrm{TE} / \mathrm{g}\end{array}$ & $\begin{array}{l}\text { ABTS } \\
\mu \mathrm{mol} \mathrm{TE} / \mathrm{g}\end{array}$ & $\begin{array}{l}\text { FRAP } \\
\mu \mathrm{mol} \mathrm{Fe} / \mathrm{g}\end{array}$ \\
\hline 1 & $9.54 \pm 0.07$ & $3.82 \pm 0.03$ & 0.40 & $32.25 \pm 0.07$ & $41.67 \pm 0.07$ & $37 \pm 3$ \\
2 & $13.33 \pm 0.03$ & $5.54 \pm 0.05$ & 0.42 & $37.5 \pm 0.2$ & $46.8 \pm 0.3$ & $66 \pm 3$ \\
3 & $10.11 \pm 0.07$ & $4.15 \pm 0.07$ & 0.41 & $34.0 \pm 0.3$ & $43.8 \pm 0.2$ & $55 \pm 2$ \\
4 & $10.54 \pm 0.09$ & $4.60 \pm 0.02$ & 0.44 & $35.1 \pm 0.2$ & $43.04 \pm 0.07$ & $45 \pm 2$ \\
5 & $9.91 \pm 0.05$ & $3.57 \pm 0.07$ & 0.36 & $33.0 \pm 0.3$ & $42.2 \pm 0.1$ & $30 \pm 2$ \\
6 & $10.91 \pm 0.07$ & $4.47 \pm 0.03$ & 0.41 & $37.1 \pm 0.1$ & $46.2 \pm 0.2$ & $71 \pm 3$ \\
7 & $12.68 \pm 0.05$ & $4.78 \pm 0.07$ & 0.38 & $36.5 \pm 0.1$ & $44.7 \pm 0.1$ & $70.1 \pm 0.8$ \\
8 & $11.46 \pm 0.09$ & $5.05 \pm 0.03$ & 0.44 & $35.9 \pm 0.2$ & $45.43 \pm 0.07$ & $75 \pm 2$ \\
\hline
\end{tabular}


The content of TP in hop samples was in the range $9.54 \mathrm{mg} \mathrm{GAE} / \mathrm{g}-13.33 \mathrm{mg}$ GAE/g. The data obtained in this study are comparable to the results reported by Kirca and Arslan [24] and by Lermusieau et al. [38] while the results published by Proestos et al. [39], Mudura et al. [22] and Wojdylo et al. [19] were significantly lower. Higher TP content $(23.1 \mathrm{mg} / \mathrm{g}$ and $151.42 \mathrm{mg} / \mathrm{g})$ in hop extract was determined by Kahkonen et al. [20] and by Arsene et al. [18]. The content of TF in hop samples was in the range $3.57 \mathrm{mg} \mathrm{CE} / \mathrm{g}-5.54 \mathrm{mg} \mathrm{CE} / \mathrm{g}$, which is $36 \%-44 \%$ from TP content.

Ethanol hop extracts showed relatively good radical-scavenging properties toward stable DPPH radical. The obtained results of DPPH radical scavenging activity ranged from $32.25 \mu \mathrm{mol} \mathrm{TE} / \mathrm{g}$ to $37.5 \mu \mathrm{mol} \mathrm{TE} / \mathrm{g}$, for ABTS from $41.67 \mu \mathrm{mol} \mathrm{TE} / \mathrm{g}$ to $46.8 \mu \mathrm{mol} \mathrm{TE} / \mathrm{g}$ and for FRAP assay from 30 $\mu \mathrm{mol} \mathrm{Fe} / \mathrm{g}$ to $75 \mu \mathrm{mol} \mathrm{Fe} / \mathrm{g}$. The highest values of TP, TF, DPPH and ABTS were obtained for sample no. 2, while the highest values for FRAP were measured for sample 8. The lowest values of TP, DPPH, ABTS were determined for sample 1, while sample 5 has the lowest values for TF and FRAP.

\subsection{HPLC analyses of individual phenolic compounds in hop strobili extract}

In order to identify and quantify individual phenolic compounds, the content of flavonols, phenolic acids and flavan-3-ols was determined applying HPLC method. Seven phenolic compounds of quercetin and kaempferol were identified at $360 \mathrm{~nm}$ : quercetin-3-galactoside, quercetin-3-rutinoside, quercetin-3-glucoside, kaempferol-3-rutinoside, kaempferol-3-glucoside, quercetin-glycoside and kaempferol-glycoside (Figure 1a). Four phenolic acids (4-hydroxybenzoic, chlorogenic, p-coumaric and ferulic) were identified at $320 \mathrm{~nm}$ (Figure 1b). The chromatographic profile for four flavan-3-ols (procyanidin $\mathrm{B} 1$, catechin, procyanidin $\mathrm{B} 2$ and epicatechin) identified using fluorescence detector at 275/322 $\mathrm{nm}$ is presented in Figure 1c.

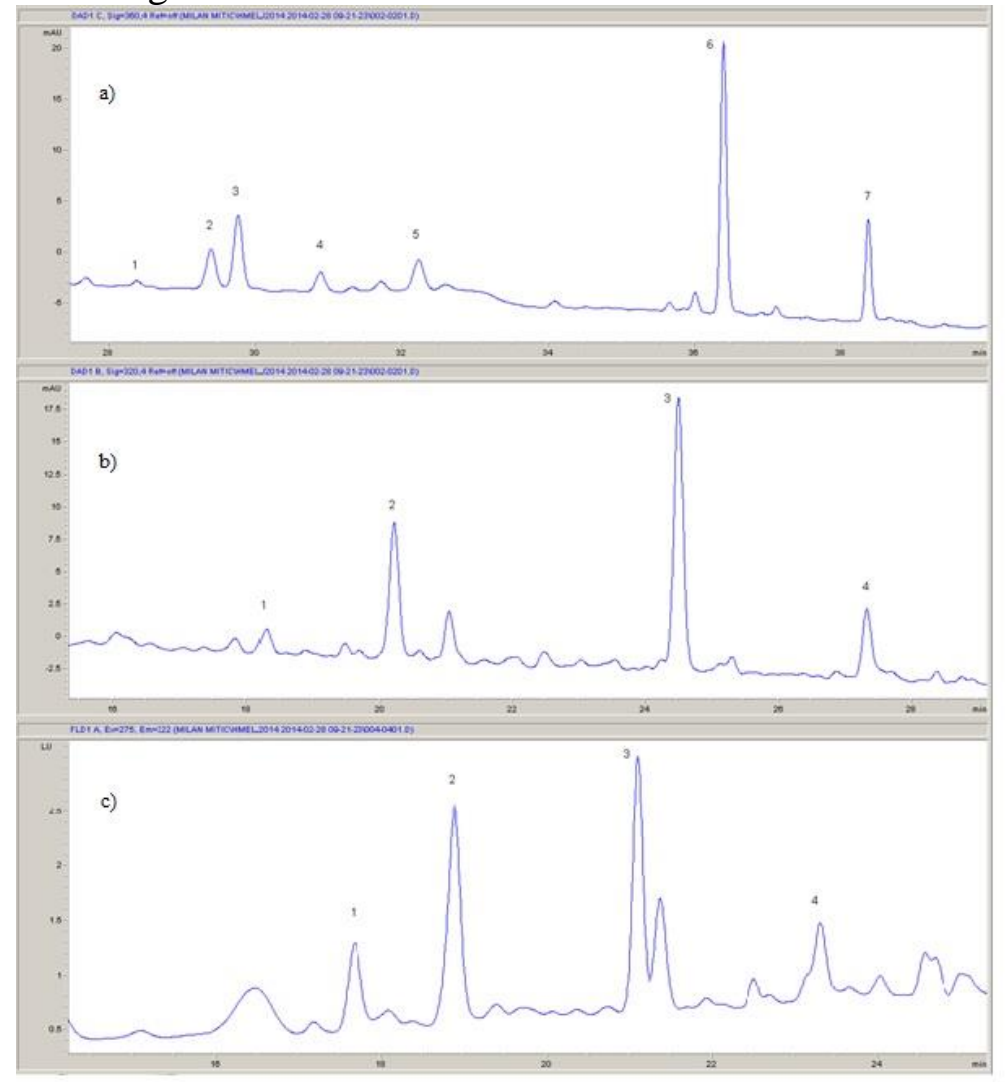

Figure 1. HPLC chromatograms of ethanol hop extract recorded at: a) $360 \mathrm{~nm}$ :

1) quercetin-3-galactoside; 2) quercetin-3-rutinoside; 3) quercetin-3-glucoside;

4) kaempferol-3-rutinoside; 5) kaempferol-3-glucoside; 6) quercetin-glycoside and 7) kaempferolglycoside; b) $320 \mathrm{~nm}$ : 1) 4-hydroxybenzoic acid; 2) chlorogenic acid; 3) p-coumaric acid and 4) ferulic acid; c) $275 / 322 \mathrm{~nm}\left(\lambda_{\mathrm{ex}} / \lambda_{\mathrm{em}}\right)$ : 1) procyanidin B1;2) catechin; 3) procyanidin B2 and 4) epicatechin. 
The results of flavonols, phenolic acids and flavan-3-ols contents in eight hop samples are listed in Table 3. The total content of flavonols was in the range $0.338 \mathrm{mg} / \mathrm{g}-1.427 \mathrm{mg} / \mathrm{g}$. In all hop samples, quercetin-glycoside $(0.158 \mathrm{mg} / \mathrm{g}-0.536 \mathrm{mg} / \mathrm{g})$ is the major phenolic compound. The total content of quercetin-glycosides $(0,290 \mathrm{mg} / \mathrm{g}-0.965 \mathrm{mg} / \mathrm{g})$ was higher than the total content of kaempferolglycosides $(0.048 \mathrm{mg} / \mathrm{g}-0.546 \mathrm{mg} / \mathrm{g})$. These results were in accordance with those given by Kovačova et al. [40], $(0.165 \mathrm{mg} / \mathrm{g}$ and $0.126 \mathrm{mg} / \mathrm{g})$, while results reported by McMurrough et al. [41] were 0.92 $\mathrm{mg} / \mathrm{g}$ for quercetin-glycosides and $1.20 \mathrm{mg} / \mathrm{g}$ for kaempferol-glycosides.

Total phenolic acids content was in the interval $0.286 \mathrm{mg} / \mathrm{g}-0.752 \mathrm{mg} / \mathrm{g}$. Chlorogenic acid with concentration interval $0.152 \mathrm{mg} / \mathrm{g}-0.349 \mathrm{mg} / \mathrm{g}$ is the major phenolic acid in all hop extracts. The phenolic acid found in the lowest concentration is 4-hydroxybenzoic acid $(0.018 \mathrm{mg} / \mathrm{g}-0.124 \mathrm{mg} / \mathrm{g}) . \mathrm{p}$ coumaric acid $(0.019 \mathrm{mg} / \mathrm{g}-0.203 \mathrm{mg} / \mathrm{g})$ and ferulic acid $(0.039 \mathrm{mg} / \mathrm{g}-0.098 \mathrm{mg} / \mathrm{g})$ are detected as well. Proestos et al. [39] published very similar results for 4-hydroxybenzoic acid $(0.015 \mathrm{mg} / \mathrm{g})$ and pcoumaric acid $(0.038 \mathrm{mg} / \mathrm{g})$, but ferulic acid was not detected. The higher contents of $\mathrm{p}$-coumaric acid $(0.228 \mathrm{mg} / \mathrm{g})$ and ferulic acid $(0.143 \mathrm{mg} / \mathrm{g})$ in hop were reported by Wojdylo et al. [19].

Total quantity of flavan-3-ols was determined in the range $0.429 \mathrm{mg} / \mathrm{g}-0.996 \mathrm{mg} / \mathrm{g}$. In all hop extracts, procyanidin B2 $(0.132 \mathrm{mg} / \mathrm{g}-0.416 \mathrm{mg} / \mathrm{g})$ was the major, while epicatechin (nd $-0.159 \mathrm{mg} / \mathrm{g}$ ) was the minor phenolic component. The similar content of catechin $(0.238 \mathrm{mg} / \mathrm{g})$, but significantly higher quantity of epicatechin $(1.438 \mathrm{mg} / \mathrm{g})$ was reported by Callemien et al. [42]. Magalhaes et al. confirmed presence of catechin, epicatechin and procyanidin in hop extracts [43]. Proestos et al. reported that catechin is the most common flavan-3-ol in plant materials [39].

Table 3. Flavonols, phenolic acids and flavan-3-ols content in the hop extracts (mg/g)

\begin{tabular}{|c|c|c|c|c|c|c|c|c|}
\hline \multirow{2}{*}{ Compound } & \multicolumn{8}{|c|}{ Sample } \\
\hline & 1 & 2 & 3 & 4 & 5 & 6 & 7 & 8 \\
\hline \multicolumn{9}{|c|}{ Flavonols } \\
\hline Quercetin-3-galactoside & 0.015 & 0.017 & 0.036 & 0.041 & 0.050 & 0.027 & 0.029 & 0.068 \\
\hline Quercetin-3-rutinoside & 0.035 & 0.033 & 0.091 & 0.077 & 0.236 & 0.122 & 0.034 & 0.248 \\
\hline Quercetin-3-glucoside & 0.082 & 0.135 & 0.319 & 0.178 & 0.177 & 0.236 & 0.108 & 0.187 \\
\hline Kaempferol-3-rutinoside & 0.048 & 0.051 & 0.122 & 0.058 & 0.049 & 0.070 & 0.058 & 0.068 \\
\hline Kaempferol-3-glucoside & nd & nd & 0.220 & 0.099 & 0.088 & 0.115 & nd & 0.086 \\
\hline Quercetin-glycoside & 0.158 & 0.459 & 0.435 & 0.536 & 0.438 & 0.394 & 0.460 & 0.462 \\
\hline Kaempferol-glycoside & nd & nd & 0.204 & 0.177 & 0.154 & 0.120 & 0.095 & 0.153 \\
\hline $\boldsymbol{\Sigma}$ Quercetin glycosides & 0.290 & 0.644 & 0.881 & 0.832 & 0.901 & 0.779 & 0.631 & 0.965 \\
\hline $\boldsymbol{\Sigma}$ Kaempferol glycosides & 0.048 & 0.051 & 0.546 & 0.334 & 0.291 & 0.305 & 0.153 & 0.307 \\
\hline$\Sigma$ Flavonols & 0.338 & 0.695 & 1.427 & 1.166 & 1.192 & 1.084 & 0.784 & 1.272 \\
\hline \multicolumn{9}{|c|}{ Phenolic acids } \\
\hline 4-hydroxybenzoic & 0.018 & 0.020 & 0.124 & 0.111 & 0.047 & 0.019 & 0.018 & 0.118 \\
\hline Chlorogenic & 0.152 & 0.316 & 0.349 & 0.304 & 0.257 & 0.294 & 0.273 & 0.245 \\
\hline p-coumaric & 0.040 & 0.019 & 0.203 & 0.197 & 0.178 & 0.194 & 0.191 & 0.176 \\
\hline Ferulic & 0.076 & 0.039 & 0.076 & 0.073 & 0.085 & 0.066 & 0.067 & 0.098 \\
\hline$\Sigma$ Phenolic acids & 0.286 & 0.394 & 0.752 & 0.685 & 0.567 & 0.573 & 0.549 & 0.637 \\
\hline \multicolumn{9}{|c|}{ Flavan-3-ols } \\
\hline Procyanidin B1 & 0.131 & 0.165 & 0.143 & 0.123 & 0.089 & 0.117 & 0.148 & 0.079 \\
\hline Catechin & 0.264 & 0.229 & 0.278 & 0.209 & 0.112 & 0.249 & 0.255 & 0.115 \\
\hline Procyanidin B2 & 0.311 & 0.339 & 0.416 & 0.310 & 0.260 & 0.331 & 0.325 & 0.132 \\
\hline Epicatechin & nd & nd & 0.159 & 0.107 & 0.084 & nd & 0.159 & 0.103 \\
\hline$\Sigma$ Flavan-3-ols & 0.706 & 0.733 & 0.996 & 0.749 & 0.545 & 0.697 & 0.887 & 0.429 \\
\hline
\end{tabular}

\subsection{ICP-OES analyses of hop strobili mineral content}

Experimental values of hop mineral content were expressed as mean value $(\mu \mathrm{g} / \mathrm{g}) \pm \mathrm{SD}$ for three replicate measurements and three groups of elements were established for obtained data (Tables 4, 5 and 6). 
Table 4. The major elements content $(\mu \mathrm{g} / \mathrm{g})$ in hop strobili samples.

\begin{tabular}{cccccc}
\hline Sample & \multicolumn{5}{c}{ Element } \\
\cline { 2 - 6 } & $\mathrm{K}$ & $\mathrm{Na}$ & $\mathrm{Ca}$ & $\mathrm{Mg}$ & $\mathrm{Na} / \mathrm{K}$ \\
\hline 1 & $10511 \pm 5$ & $89.3 \pm 0.2$ & $1253.6 \pm 0.9$ & $2056 \pm 2$ & 0.008 \\
2 & $10603 \pm 2$ & $78.7 \pm 0.2$ & $1198.2 \pm 0.3$ & $2102.5 \pm 0.7$ & 0.007 \\
3 & $9688 \pm 3$ & $82 \pm 1$ & $1224.2 \pm 0.1$ & $1945.6 \pm 0.7$ & 0.008 \\
4 & $10124.5 \pm 0.6$ & $88.5 \pm 0.1$ & $1097 \pm 1$ & $1987.5 \pm 0.8$ & 0.009 \\
5 & $10423 \pm 1$ & $89.67 \pm 0.09$ & $1255.4 \pm 0.2$ & $2176.4 \pm 0.3$ & 0.009 \\
6 & $10734 \pm 2$ & $85.71 \pm 0.04$ & $1175.8 \pm 0.8$ & $1874.6 \pm 0.5$ & 0.008 \\
7 & $10066 \pm 3$ & $80.1 \pm 0.1$ & $1167.5 \pm 0.4$ & $2067 \pm 1$ & 0.008 \\
8 & $11007 \pm 4$ & $83.7 \pm 0.3$ & $1202.5 \pm 0.6$ & $2115.3 \pm 0.6$ & 0.008 \\
\hline
\end{tabular}

Potassium concentration ranged from $9688 \mu \mathrm{g} / \mathrm{g}$ to $11007 \mu \mathrm{g} / \mathrm{g}$, while sodium was the metal present in the lowest concentrations $(78.7 \mu \mathrm{g} / \mathrm{g}-89.67 \mu \mathrm{g} / \mathrm{g})$. Considering this, $\mathrm{Na} / \mathrm{K}$ coefficients values were significantly low for all eight samples due to the high $\mathrm{K}$ content in all samples. The evaluated $\mathrm{Ca}$ content was in the interval of $1097 \mu \mathrm{g} / \mathrm{g}-1255.4 \mu \mathrm{g} / \mathrm{g}$, while $\mathrm{Mg}$ concentrations were in the range of $1874.6 \mu \mathrm{g} / \mathrm{g}-2176.4 \mu \mathrm{g} / \mathrm{g}$. Ghiselli et al. published elements concentrations in hop that are mostly in accordance with results of presented research, except for Ca that are 10 times higher $(9380 \mathrm{mg} / \mathrm{kg}-$ $15515 \mathrm{mg} / \mathrm{kg}$ ) [44]. Liu et al. quantified approximately the same content of $\mathrm{Ca}$ and $\mathrm{Na}$ as it was determined in this study, but two times higher concentration of $\mathrm{Mg}$ and 5 times smaller concentration of $\mathrm{K}$ [16]. Our research revealed the major elements content in hop samples decreased as following: $\mathrm{K}>\mathrm{Mg}>\mathrm{Ca}>\mathrm{Na}$.

The results of minor elements content in hop extracts are presented in Table 5.

Table 5. The minor elements content $(\mu \mathrm{g} / \mathrm{g})$ in hop strobili samples.

\begin{tabular}{ccccccc}
\hline Sample & \multicolumn{7}{c}{ Element } \\
\cline { 2 - 6 } & $\mathrm{Fe}$ & $\mathrm{Cu}$ & $\mathrm{Mn}$ & $\mathrm{Zn}$ & $\mathrm{Co}$ & $\mathrm{Cr}$ \\
\hline 1 & $83.15 \pm 0.05$ & $8.92 \pm 0.02$ & $31.49 \pm 0.04$ & $39.18 \pm 0.09$ & $0.081 \pm 0.005$ & $0.781 \pm 0.001$ \\
2 & $65.9 \pm 0.1$ & $9.54 \pm 0.02$ & $32.8 \pm 0.1$ & $31.7 \pm 0.1$ & $0.052 \pm 0.006$ & $0.456 \pm 0.006$ \\
3 & $82.0 \pm 0.3$ & $9.776 \pm 0.009$ & $28.56 \pm 0.01$ & $42.74 \pm 0.03$ & $0.075 \pm 0.001$ & $0.678 \pm 0.006$ \\
4 & $73 \pm 1$ & $8.93 \pm 0.02$ & $28.54 \pm 0.04$ & $37.7 \pm 0.1$ & $0.085 \pm 0.003$ & $0.871 \pm 0.001$ \\
5 & $79.6 \pm 0.2$ & $8.113 \pm 0.008$ & $30.75 \pm 0.05$ & $36.8 \pm 0.2$ & $0.091 \pm 0.005$ & $0.61 \pm 0.01$ \\
6 & $85.1 \pm 0.2$ & $7.47 \pm 0.01$ & $31.77 \pm 0.04$ & $36.43 \pm 0.08$ & $0.035 \pm 0.001$ & $0.688 \pm 0.004$ \\
7 & $84.6 \pm 0.1$ & $8.354 \pm 0.007$ & $31.89 \pm 0.09$ & $39.8 \pm 0.2$ & $0.058 \pm 0.009$ & $0.487 \pm 0.005$ \\
8 & $76.03 \pm 0.09$ & $7.881 \pm 0.005$ & $33.04 \pm 0.05$ & $35.75 \pm 0.04$ & $0.066 \pm 0.002$ & $0.556 \pm 0.009$ \\
\hline Sample & $\mathrm{Se}$ & $\mathrm{Si}$ & $\mathrm{V}$ & $\mathrm{Mo}$ & $\mathrm{Ni}$ & $\mathrm{Sn}$ \\
\hline 1 & $0.631 \pm 0.003$ & $12.02 \pm 0.01$ & $7.93 \pm 0.06$ & $1.23 \pm 0.03$ & $0.723 \pm 0.001$ & $0.681 \pm 0.001$ \\
2 & $0.667 \pm 0.006$ & $11.56 \pm 0.01$ & $8.65 \pm 0.02$ & $2.056 \pm 0.009$ & $0.564 \pm 0.009$ & $0.792 \pm 0.001$ \\
3 & $0.345 \pm 0.006$ & $12.67 \pm 0.05$ & $8.014 \pm 0.009$ & $1.89 \pm 0.01$ & $0.792 \pm 0.002$ & $0.626 \pm 0.002$ \\
4 & $0.17 \pm 0.01$ & $9.6 \pm 0.1$ & $9.02 \pm 0.08$ & $1.346 \pm 0.004$ & $0.694 \pm 0.002$ & $0.46 \pm 0.01$ \\
5 & $0.38 \pm 0.01$ & $11.74 \pm 0.09$ & $7.12 \pm 0.06$ & $1.68 \pm 0.02$ & $0.61 \pm 0.01$ & $0.667 \pm 0.008$ \\
6 & $0.455 \pm 0.008$ & $9.45 \pm 0.01$ & $7.765 \pm 0.008$ & $1.125 \pm 0.008$ & $0.705 \pm 0.007$ & $0.551 \pm 0.002$ \\
7 & $0.42 \pm 0.01$ & $8.98 \pm 0.05$ & $8.34 \pm 0.02$ & $1.87 \pm 0.02$ & $0.642 \pm 0.006$ & $0.611 \pm 0.008$ \\
8 & $0.527 \pm 0.009$ & $10.64 \pm 0.09$ & $7.75 \pm 0.09$ & $1.254 \pm 0.007$ & $0.648 \pm 0.002$ & $0.712 \pm 0.001$ \\
\hline
\end{tabular}

The minor elements content in hop samples decreased as following: $\mathrm{Fe}>\mathrm{Zn}>\mathrm{Mn}>\mathrm{Cu}>\mathrm{Si}>\mathrm{V}>\mathrm{Mo}>$ $\mathrm{Ni} \approx \mathrm{Cr} \approx \mathrm{Sn}>\mathrm{Se}>\mathrm{Co}$. The highest content among these elements in all samples was determined for $\mathrm{Fe}$ $(65.9 \mu \mathrm{g} / \mathrm{g}-85.1 \mu \mathrm{g} / \mathrm{g})$. Zinc was measured in concentration range $31.7 \mu \mathrm{g} / \mathrm{g}-42.74 \mu \mathrm{g} / \mathrm{g}$, while manganese content in studied samples was about $30 \mu \mathrm{g} / \mathrm{g}$. Copper concentration range was $7.47 \mu \mathrm{g} / \mathrm{g}-$ $9.776 \mu \mathrm{g} / \mathrm{g}$, while cobalt was quantified in the interval of $0.035 \mu \mathrm{g} / \mathrm{g}-0.091 \mu \mathrm{g} / \mathrm{g}$. The intervals for other elements are: $8.98 \mu \mathrm{g} / \mathrm{g}-12.67 \mu \mathrm{g} / \mathrm{g}$ (Si), $7.12 \mu \mathrm{g} / \mathrm{g}-9.02 \mu \mathrm{g} / \mathrm{g}(\mathrm{V}), 1.125 \mu \mathrm{g} / \mathrm{g}-2.056 \mu \mathrm{g} / \mathrm{g}$ (Mo), $0.564 \mu \mathrm{g} / \mathrm{g}-0.792 \mu \mathrm{g} / \mathrm{g}(\mathrm{Ni}), 0.456 \mu \mathrm{g} / \mathrm{g}-0.871 \mu \mathrm{g} / \mathrm{g}(\mathrm{Cr}), 0.46 \mu \mathrm{g} / \mathrm{g}-0.792 \mu \mathrm{g} / \mathrm{g}$ (Sn) and $0.17 \mu \mathrm{g} / \mathrm{g}-$ $0.667 \mu \mathrm{g} / \mathrm{g}$ (Se). Ghiselli et al. presented partly similar or, for some of these elements, higher results ( $\mathrm{Si}, \mathrm{V}, \mathrm{Mo}$ and Se were not examined in hop samples), while $\mathrm{Cr}$ and $\mathrm{Ni}$ content was higher, four times and ten times, respectively [44]. Liu et al. reported several times higher concentration of $\mathrm{Fe}, \mathrm{Mn}, \mathrm{Cr}$ and $\mathrm{Co}$, but lower content for $\mathrm{Zn}$ compared to the quantified concentrations of these elements in this paper. In their research, the analysis of hop for Se, Si, Mo and Sn had not been done. Their samples 
had up to 4 times higher content of $\mathrm{Ni}$, but about 7 times lower content of $\mathrm{V}$ compared to the results reported in this study [16]. Melandrino et al. analyzed hop for the presence of Se and Sn but did not quantified these elements in samples they used [45]. A thorough search of the relevant literature yielded published articles that analyzed and quantified Sn and Se in hops.

The results of nonessential elements determination are shown in Table 6.

Table 6. Nonessential elements content $(\mu \mathrm{g} / \mathrm{g})$ in hop samples

\begin{tabular}{ccccc}
\hline Sample & \multicolumn{4}{c}{ Element } \\
\cline { 2 - 5 } & $\mathrm{As}$ & $\mathrm{Pb}$ & $\mathrm{Cd}$ & $\mathrm{Al}$ \\
\hline 1 & $0.35 \pm 0.05$ & $0.471 \pm 0.009$ & $0.098 \pm 0.003$ & $15.4 \pm 0.1$ \\
2 & $0.11 \pm 0.04$ & $0.193 \pm 0.005$ & $0.066 \pm 0.001$ & $16.66 \pm 0.09$ \\
3 & $0.36 \pm 0.06$ & $0.38 \pm 0.01$ & $0.078 \pm 0.001$ & $15.0 \pm 0.2$ \\
4 & $0.21 \pm 0.04$ & $0.301 \pm 0.009$ & $0.092 \pm 0.003$ & $14.7 \pm 0.1$ \\
5 & $0.30 \pm 0.04$ & $0.50 \pm 0.02$ & $0.055 \pm 0.004$ & $13.88 \pm 0.02$ \\
6 & $0.28 \pm 0.01$ & $0.22 \pm 0.02$ & $0.082 \pm 0.002$ & $15.32 \pm 0.08$ \\
7 & $0.24 \pm 0.01$ & $0.157 \pm 0.005$ & $0.098 \pm 0.001$ & $14.7 \pm 0.2$ \\
8 & $0.38 \pm 0.08$ & $0.29 \pm 0.03$ & $0.059 \pm 0.003$ & $16.0 \pm 0.1$ \\
\hline Sample & $\mathrm{Ba}$ & $\mathrm{Li}$ & $\mathrm{Sr}$ & $\mathrm{Sb}$ \\
\hline 1 & $4.22 \pm 0.02$ & $6.125 \pm 0.008$ & $9.234 \pm 0.005$ & $0.537 \pm 0.001$ \\
2 & $4.002 \pm 0.008$ & $5.876 \pm 0.009$ & $7.653 \pm 0.002$ & $0.455 \pm 0.002$ \\
3 & $3.453 \pm 0.009$ & $6.711 \pm 0.002$ & $6.98 \pm 0.01$ & $0.565 \pm 0.008$ \\
4 & $3.769 \pm 0.002$ & $7.026 \pm 0.009$ & $7.112 \pm 0.001$ & $0.49 \pm 0.01$ \\
5 & $4.319 \pm 0.001$ & $6.111 \pm 0.003$ & $7.656 \pm 0.006$ & $0.546 \pm 0.005$ \\
6 & $4.07 \pm 0.01$ & $7.83 \pm 0.01$ & $8.62 \pm 0.02$ & $0.435 \pm 0.002$ \\
7 & $2.871 \pm 0.009$ & $6.165 \pm 0.003$ & $8.142 \pm 0.008$ & $0.378 \pm 0.005$ \\
8 & $3.886 \pm 0.001$ & $6.664 \pm 0.009$ & $9.189 \pm 0.005$ & $0.466 \pm 0.001$ \\
\hline
\end{tabular}

The mean concentrations of third group elements were increasing in the following order: $\mathrm{Cd}<\mathrm{As}<\mathrm{Pb}<\mathrm{Sb}<\mathrm{Ba}<\mathrm{Li}<\mathrm{Sr}<\mathrm{Al}$. Among all nonessential elements, the highest contents of $\mathrm{Al}$ (13.88 $\mu \mathrm{g} / \mathrm{g}-16.66 \mu \mathrm{g} / \mathrm{g})$ and $\mathrm{Sr}(6.98 \mu \mathrm{g} / \mathrm{g}-9.234 \mu \mathrm{g} / \mathrm{g})$ were determined. The metals such as $\mathrm{Cd}(0.055 \mu \mathrm{g} / \mathrm{g}-$ $0.098 \mu \mathrm{g} / \mathrm{g})$, As $(0.11 \mu \mathrm{g} / \mathrm{g}-0.38 \mu \mathrm{g} / \mathrm{g}), \mathrm{Pb}(0.157 \mu \mathrm{g} / \mathrm{g}-0.50 \mu \mathrm{g} / \mathrm{g}), \mathrm{Sb}(0.378 \mu \mathrm{g} / \mathrm{g}-0.565 \mu \mathrm{g} / \mathrm{g}), \mathrm{Ba}$ $(2.871 \mu \mathrm{g} / \mathrm{g}-4.319 \mu \mathrm{g} / \mathrm{g})$ and $\mathrm{Li}(5.876 \mu \mathrm{g} / \mathrm{g}-7.83 \mu \mathrm{g} / \mathrm{g})$ were also quantified. Two times higher concentrations for $\mathrm{Cd}$, twenty times for $\mathrm{Ba}$ and about five times for $\mathrm{Sr}$, were reported by Ghiselli et al. [44]. Seven times higher content of $\mathrm{Al}$, up to two times higher content of $\mathrm{Cd}, 35$ times higher amount of $\mathrm{Sr}$ and approximately the same amount of $\mathrm{As}$ and $\mathrm{Pb}$ were presented by $\mathrm{Li}$ et al. [16]. A thorough search of the relevant literature yielded published articles that analyzed and quantified $\mathrm{Sb}$ in hops.

\subsection{Statistical analyses of quantities of total phenols, total flavonoids, antioxidant capacity and mineral content of hop strobili}

\subsubsection{Principal component analysis (PCA)}

PCA was applied to the entire data set and six principal components with eigenvalues higher than 1 were obtained, explaining $97.264 \%$ of variability. The first component explained $36.881 \%$, the second $21.863 \%$, the third $16.186 \%$, the fourth $9.525 \%$, the fifth $7.431 \%$ and the six component $5.378 \%$. The PCA results are displayed in Table 7 and Figure 2. The first component explained the largest portion of the variance with significant loadings of following variables: DPPH, ABTS, FRAP, TP, TF, Na, Co, $\mathrm{Cr}, \mathrm{Pb}, \mathrm{Sb}$ (highest loadings), K, $\mathrm{Ca}, \mathrm{Fe}, \mathrm{Mn}, \mathrm{Zn}, \mathrm{Se}, \mathrm{Si}, \mathrm{V}, \mathrm{Ni}, \mathrm{Sn}, \mathrm{As}$ and $\mathrm{Al}$ (moderate loadings) and $\mathrm{Cu} \mathrm{Mg}, \mathrm{Mo}, \mathrm{Cd}, \mathrm{Ba}, \mathrm{Li}$ and $\mathrm{Sr}$ (low loadings). On the first component $\mathrm{Sb}, \mathrm{Pb}, \mathrm{Cr}, \mathrm{Co}, \mathrm{Na}, \mathrm{Ca}, \mathrm{Fe}, \mathrm{Zn}$, $\mathrm{Si}, \mathrm{Ni}$ and As have opposite influence compared to DPPH, ABTS, FRAP, TP and TF. This means that these elements are negatively correlated with antioxidant capacity tests and TP and TF content (i.e. if lower concentrations of $\mathrm{Sb}, \mathrm{Pb}, \mathrm{Cr}, \mathrm{Co}, \mathrm{Na}, \mathrm{Ca}, \mathrm{Fe}, \mathrm{Zn}, \mathrm{Si}, \mathrm{Ni}$ and As are present, values of $\mathrm{DPPH}$, ABTS, FRAP and TP and TF are higher). K, Mn Se, V, Sn and Al are positively correlated with TP and TF content and antioxidant capacity tests. Variables with significant loadings for the second component are $\mathrm{Ca}, \mathrm{Mg}$ and $\mathrm{Sn}$. 
Table 7. Factor coordinates of the variables, based on correlations

\begin{tabular}{|c|c|c|c|c|c|c|}
\hline & & & & & & \\
\hline & -0.919 & -0.323 & 0.085 & -0.055 & 0.026 & \\
\hline & & & & & & \\
\hline & -0.822 & & & & & \\
\hline & -0.954 & & & & & \\
\hline & & & & & & \\
\hline K & & & & & & \\
\hline $\mathrm{Na}$ & & & & & & \\
\hline & & & & & & \\
\hline $\mathrm{Mg}$ & -0.076 & 746 & & & & \\
\hline $\mathrm{Fe}$ & 0.455 & -0.243 & 0.485 & 623 & -0.2 & -0.036 \\
\hline $\mathrm{Cu}$ & & & & & & \\
\hline $\mathrm{Mn}$ & -0.684 & & & & & -0.196 \\
\hline $\mathrm{Zn}$ & & & & & & -0.068 \\
\hline Co & & & -0.3 & -0.2 & & -0.137 \\
\hline $\mathrm{Cr}$ & & -0.412 & 0.181 & & & -0.191 \\
\hline $\mathrm{Se}$ & -0.441 & 0.693 & 0.160 & 0.25 & 0.284 & -0.331 \\
\hline $\mathrm{Si}$ & 0.424 & 0.629 & -0.400 & 0.202 & 0.448 & 0.138 \\
\hline V & -0.376 & -0.56 & -0.461 & -0.306 & & -0.400 \\
\hline Mo & & & & & & 0.176 \\
\hline $\mathrm{Ni}$ & 0.612 & -0.475 & & & & 0.007 \\
\hline Sn & -0.374 & & & 267 & & -0.039 \\
\hline As & & & & 0.471 & & 0.095 \\
\hline $\mathrm{Pb}$ & 0.879 & 0.467 & -0.022 & -0.072 & 0.046 & 0.020 \\
\hline $\mathrm{Cd}$ & 0.154 & -0.639 & 0.019 & 0.195 & 0.039 & -0.693 \\
\hline $\mathrm{Al}$ & -0.691 & 0.260 & 0.034 & 0.018 & 0.633 & -0.181 \\
\hline $\mathrm{Ba}$ & 0.268 & 0.597 & 0.333 & -0.536 & 0.319 & 0.116 \\
\hline $\mathrm{Li}$ & 0.065 & -0.626 & 0.603 & -0.112 & 0.281 & 0.383 \\
\hline $\mathrm{Sr}$ & -0.148 & 0.377 & 0.771 & 0.191 & 0.025 & -0.433 \\
\hline $\mathrm{Sb}$ & 0.796 & 0.351 & -0.250 & -0.060 & 0.367 & 0.195 \\
\hline
\end{tabular}

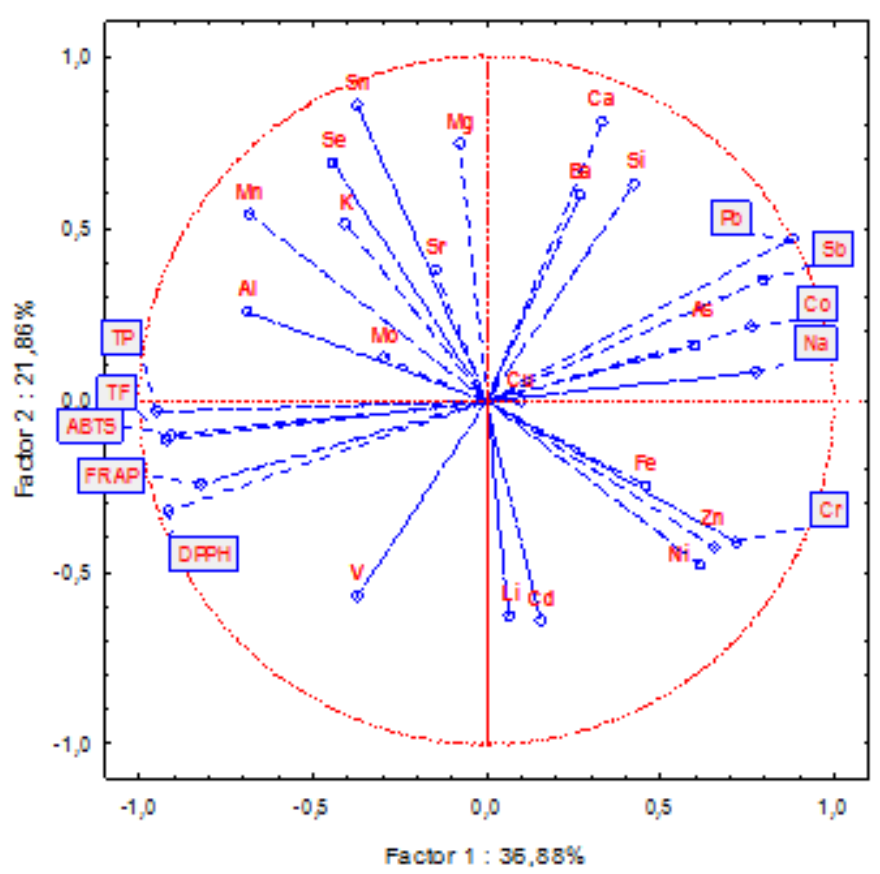

Figure 2. Projection of the variables on the factor plane (F1-F2) 
According to the Table 7 and Figure 2 it can be observed that there is a strong positive relationship between DPPH, FRAP, ABTS, TP and TF. Group of elements ( $\mathrm{Pb}, \mathrm{Sb}, \mathrm{Co}, \mathrm{Na}$ and $\mathrm{Cr}$ ) with highly positive factors is strongly negatively correlated with polyphenols and antioxidant tests.

\subsubsection{Cluster analyses}

Upon standardization of variables, Ward's method with squared Euclidian distance was used as a measure of proximity between the samples. Obtained dendrogram (Figure 3) presents clustering of hop strobili samples. Horizontal cluster analyses (HCA) showed that all the samples could be grouped into two main clusters. Cluster I was consisted of samples 7, 8, 6 and 2, while cluster II was formed by samples 4, 3, 5 and 1. The samples of cluster I are characterized by lower content of $\mathrm{Pb}, \mathrm{Sb}, \mathrm{Co}, \mathrm{Na}$ and $\mathrm{Cr}$ and higher content of TP and TF and higher antioxidant capacity. The samples of cluster II are characterized by higher content of these metals and lower content of TP and TF and lower antioxidant capacity. Further analyses showed better similarity of samples by grouping them into the subclusters (S1 and S5 are similar to each other, and the nearest samples to them are S3 and S4, which are also similar to each other). The samples S8 and S6 are close to each other, while the sample S7 does have some similarities to either S8 or S6 (or both), but also with S2.

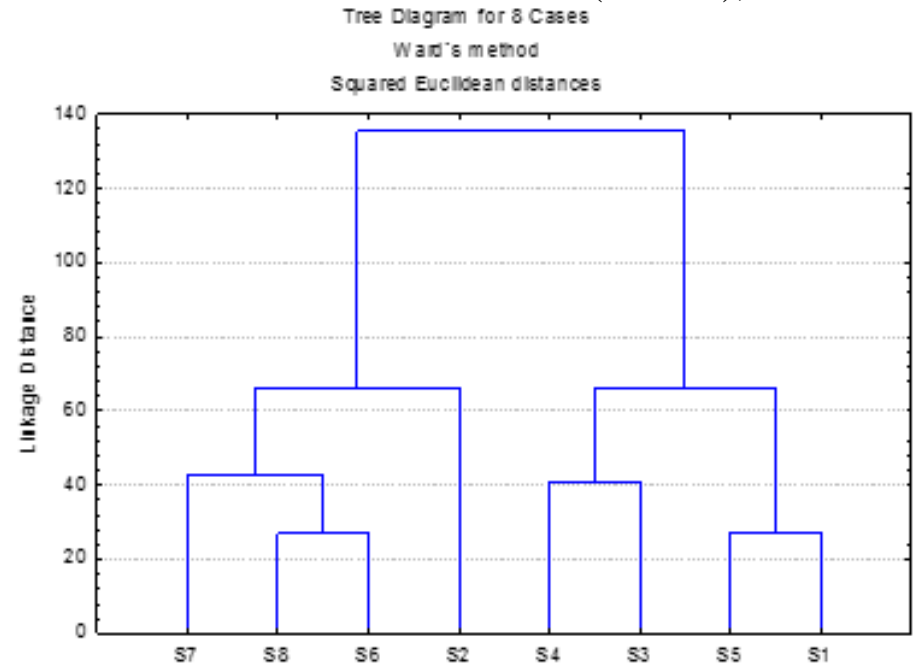

Figure 3. Dendrogram of cluster analyses of hop strobili samples (S) 1-8

\section{Conclusions}

The results of mineral content effect on TP and TF content, as well as on antioxidant activities of hop strobili are presented in this paper. The content of TP was determined in interval 9.54-13.33 mg GAE/g. TF were quantified in the range 3.57-5.54 mg CE/g. Hop extracts showed ability of neutralization DPPH (32.25-37.52 $\mu \mathrm{mol} \mathrm{TE} / \mathrm{g})$ and ABTS $(41.67-46.85 \mu \mathrm{mol} \mathrm{TE} / \mathrm{g})$ radicals, as well as high potential to reduce $\mathrm{Fe}^{3+}$ measured by FRAP assay $(30.50-75.48 \mu \mathrm{mol} \mathrm{Fe} / \mathrm{g})$. Results obtained for these antioxidant assays have following trend FRAP>ABTS $>$ DPPH. Hop extracts that do not follow this trend are sample 1 (ABTS $>$ FRAP $>$ DPPH) and sample 5 (ABTS $>$ DPPH $>$ FRAP). These two samples have the lowest content of TP and TF and the lowest antioxidant capacity, but have the highest total content of $\mathrm{Pb}, \mathrm{Sb}, \mathrm{Co}, \mathrm{Na}$ and $\mathrm{Cr}$. The best results considering TP, TF, DPPH and ABTS values were obtained for sample 2 due to the lowest total content of $\mathrm{Pb}, \mathrm{Sb}, \mathrm{Co}, \mathrm{Na}$ and $\mathrm{Cr}$. This study also included identifications and quantification of following phenolic compounds: seven flavonols (quercetin-3-galactoside, quercetin-3-rutinoside, quercetine-3-glucoside, quercetine-3-glycoside, kaempferol-3-rutinoside, kaempferol-3-glucoside, kaempferol-3-glycoside), four phenolic acids (4hydroxybenzoic acid, chlorogenic acid, p-coumaric acid and ferulic acid) and four flavan-3-ols (procyanidin B1, catechine, procyanidin B2 and epicatechine). The content of these compounds was $0.290-0.965 \mathrm{mg} / \mathrm{g}$ for total quercetin-glycosides, $0.048-0.546 \mathrm{mg} / \mathrm{g}$ for total kaempferol glycosides, $0.285-0.752 \mathrm{mg} / \mathrm{g}$ for total phenolic acids and $0.429-0.996 \mathrm{mg} / \mathrm{g}$ for total flavan-3-ols.

Furthermore, this is the first time the mineral content (24 elements) effect on TP and TF quantities and antioxidant capacity of hop strobili was analyzed. Statistical results showed strong positive 
relationship between DPPH, FRAP, ABTS, TP and TF. Group of elements ( $\mathrm{Pb}, \mathrm{Sb}, \mathrm{Co}, \mathrm{Na}$ and $\mathrm{Cr}$ ) with highly positive factors is strongly negatively correlated with polyphenols and antioxidant tests (i.e. higher concentrations of polyphenolic compounds and higher values for antioxidant capacity were associated with lower concentrations of these, for hop, potentially toxic metals).

Acknowledgements: This research was supported by the Ministry of Education, Science and Technological Development of Republic of Serbia (Agreement Numbers 451-03-68/2020-14-200124 and 451-03-68/2020-14/ 200113).

\section{References}

1.BRAVO, L., Polyphenols: Chemistry, Dietary Sources, Metabolism, and Nutritional Significance, Nutr Rev., 56(11), 1998, 317-333. https://doi.org/10.1111/j.1753-4887.1998.tb01670.x

2. COTELlE, N., Role of Flavonoids in Oxidative Stress, Curr. Top. Med. Chem., 1(6), 2001, 569590. DOI : 10.2174/1568026013394750

3.HEIM, K.E., TAGLIAFERRO, A.R., BOBILYA, D.J., Flavonoid Antioxidants: Chemistry, Metabolism and Structure-Activity Relationships, J. Nutr. Biochem., 13(10), 2002, 572-584. https://doi.org/10.1016/S0955-2863(02)00208-5

4. RICE-EVANS, C.A., MILLER, N.J., PAGANGA, G., Structure-antioxidant Activity Relationships of Flavonoids and Phenolic Acids, Free Radic. Biol. Med., 20(7), 1996, 933-956.

https://doi.org/10.1016/0891-5849(95)02227-9

5.RICE-EVANS, C.A., MILlER, N.J., PAGANGA, G., Antioxidant Properties of Phenolic Compounds, Trends Plant Sci., 2(4), 1997, 152-159. https://doi.org/10.1016/S1360-1385(97)01018-2

6.ASHRAF M., OZTURK M., AHMAD M.S.A., Plant Adaptation and Phytoremediation, Springer Science+Business Media B.V., 2010, 71-97. DOI 10.1007/978-90-481-9370-7

7.LECHNO, S., ZAMSKI, E., TEL-OR, E., Salt Stress-Induced Responses in Cucumber Plants, $J$. Plant. Physiol., 150(1-2), 1997, 206-211. https://doi.org/10.1016/S0176-1617(97)80204-0

8.HERNANDEZ, J.A., ALMANSA, M.S., Short-term Effects of Salt Stress on Antioxidant Systems and Leaf Water Relations of Pea Leaves, Physiol. Plant., 115 (2), 2002, 251-257.

https://doi.org/10.1034/j.1399-3054.2002.1150211.x

9.ABRASH, H.I., SHIH, D., ELIAS, W., MALEKMEHR, F., A Kinetic Study of the Air Oxidation of Pyrogallol and Purpurogallin, Int. J. Chem. Kinet., 21(6), 1989, 465-476.

https://doi.org/10.1002/kin.550210609

10.FRIEDMAN, M., JURGENS, H.S., Effect of $p \mathrm{H}$ on the Stability of Plant Phenolic Compounds, $J$. Agric. Food Chem., 48(6), 2000, 2101-2110. https://doi.org/10.1021/jf990489j

11.EATON, D.R., Complexing of Metal Ions with Semiquinones. An Electron Spin Resonance Study, Inorg. Chem., 3(9), 1964, 1268-1271. https://doi.org/10.1021/ic50019a016

12.TUlYATHAN, V., BOULTON, R.B., SINGLETON, V.L., Oxygen Uptake by Gallic Acid as a Model for Similar Reactions in Wines, J. Agric. Food Chem., 37(4), 1989, 844-849.

https://doi.org/10.1021/jf00088a002

13.MORAN, J.F., KLUCAS, R.V., GRAYER, R.J., ABIAN, J., BECANA, M., Complexes of Iron with Phenolic Compounds from Soybean Nodules and Other Legume Tissues: Prooxidant and Antioxidant Properties, Free Radic. Biol. Med., 22(5), 1997, 861-870. https://doi.org/10.1016/S08915849(96)00426-1

14.PEPI, S., CHICCA, M., TELLOLI, C., DI ROMA, A., GRISENTI, P., TESSARI, U., VACCARO, C., Discrimination of Geographical Origin of Hop (Humulus lupulus L.) Using Geochemical Elements Combined with Statistical Analysis, Environ. Geochem. Health., 41(3), 2019, 1559-1576.

DOI: $10.1007 / \mathrm{s} 10653-018-0232-7$

15. OCVIRK, M., NEČEMER, M., KOŠIR, I.J., The Determination of the Geographic Origins of Hops (Humulus lupulus L.) by Multi-Elemental Fingerprinting, Food Chem., 277, 2019, 32-37. https://doi.org/10.1016/j.foodchem.2018.10.070 
16. LIU, Z., WANG, Y., LIU, Y., Geographical Origins and Varieties Identification of Hops (Humulus lupulus L.) by Multi-Metal Elements Fingerprinting and the Relationships with Functional Ingredients, Food Chem., 289, 2019, 522-530. https://doi.org/10.1016/j.foodchem.2019.03.099 17. GORJANOVIĆ, S., PASTOR, F.T., VASIĆ, R., NOVAKOVIĆ, M., SIMONOVIĆ, M., MILIĆ, S., SUŽNJEVIĆ, D., Electrochemical Versus Spectrophotometric Assessment of Antioxidant Activity of Hop (Humulus Lupulus L.) Products and Individual Compounds, J. Agric. Food Chem., 61(38), 2013, 9089-9096. https://doi.org/10.1021/jf401718z

18. ARSENE, A.L., RODINO, S., BUTU, A., PETRACHE, P., IORDACHE, O., BUTU, M., Study on Antimicrobial and Antioxidant Activity and Phenolic Content of Ethanolic Extract of Humulus Lupulus, Farmacia, 63(6), 2015, 851-857.

19. WOJDYLO, A., OSZMIANSKI, J., CZEMERYS, R. Antioxidant Activity and Phenolic Compounds in 32 Selected Herbs, Food Chem., 105(3), 2007, 940-949.

https://doi.org/10.1016/j.foodchem.2007.04.038

20. KAHKONEN, M.P., HOPIA, A.I., VUORELA, H.J., RAUHA, J.P., PIHLAJA, K., KUJALA, T.S., HEINONEN, M., Antioxidant Activity of Plant Extracts Containing Phenolic Compounds, $J$. Agric. Food Chem., 47(10), 1999, 3954-3962. https://doi.org/10.1021/jf9901461

21. Di SOTTO, A., CHECCONI, P., CELESTINO, I., LOCATELli, M., CARISSIMI, S., DE ANGEliS M., ROSSI, V., LIMONGI, D., TONIOLO, C., MARTINOLI, L., GIACOMO, S., PALAMARA, A.T., NENCIONI, L., Antiviral and Antioxidant Activity of a Hydroalcoholic Extract from Humulus lupulus L., Oxid. Med. Cell. Longev., 2018, Article ID 5919237.

https://doi.org/10.1155/2018/5919237

22. MUDURA, E., TOFANA, M., PAUCEAN, A., SOCACI, S., The Evaluation of Antioxidant Capacity of Romanian Hops, J. Agroaliment. Proc. Technol., 16(2), 2010, 262-264.

23. PREEDY, V. Beer in Health and Disease Prevention, 1st edn. Elsevier Inc. Academic Press, 2008, 467-474.

24. KIRCA, A., ARSLAN, E., Antioxidant Capacity and Total Phenolic Content of Selected Plants from Turkey, Int. J. Food Sci. Tech., 43(11), 2008, 2038-2046.

https://doi.org/10.1111/j.1365-2621.2008.01818.x

25. IACOPINI, P., BALDI, M., STORCHI, P., SEBASTIANI, L., Catechin, Epicatechin, Quercetin, Rutin and Resveratrol in Red Grape: Content, in vitro antioxidant activity and interactions, J. Food Compos. Anal., 21(8), 2008, 589-598. https://doi.org/10.1016/j.jfca.2008.03.011

26. BOROWSKA, E.J., MAZUR, B., GADZAL, R., KOPCIUCH, V., BUSZEWSKI, B., Polyphenol, Anthocyanin and Resveratrol Mass Fractions and Antioxidant Properties of Cranberry Cultivars, Food Technol. Biotechnol., 47(1), 2009, 56-61. https://hrcak.srce.hr/33053

27. KATALINIĆ, V., MOŠINA, S.S., SKROZA, D., GENERALIĆ, I., ABRAMOVIČ, H., MILOŠ, M., LJUBENKOV, I., PISKERNIK, S., PEZO, I., TERPINC, P., BOBAN, M., Polyphenolic Profile, Antioxidant Properties and Antimicrobial Activity of Grape Skin Extracts of 14 Vitis vinifera Varieties Grown in Dalmatia, Food Chem., 119(2), 2010, 715-723.

http://dx.doi.org/10.1016/j.foodchem.2009.07.019

28. RADOJEVIĆ, M., BASHKIN, V., Practical Environmental Analysis. The Royal Society of Chemistry, Cambrige, UK, 1999, 378

29. SINGLETON, V. L., ROSSI, J. A., Colorimetry of Total Phenolics with PhosphomolybdicPhosphotungstic Acid Reagents, Am. J. Enol. Vitic., 16, 1965, 144-158.

30. STRATIL, P., KLEJDUS, B., KUBAN, V., Determination of Phenolic Compounds and Their Antioxidant Activity in Fruits and Cereals. Talanta, 71, 2007, 1741-1751.

https://doi.org/10.1016/j.talanta.2006.08.012

31. ZHISHEN, J., MENGCHENG, T., JIANMING, W., The Determination of Flavonoid Contents in Mulberry and Their Scavenging Effects on Superoxide Radicals, Food Chem., 64(4), 1999, 555-559. https://doi.org/10.1016/S0308-8146(98)00102-2 
32. BRAND-WILLIAMS, W., CUVELIER, M.E., BERSET, C., Use of a Free Radical Method to Evaluate Antioxidant Activity, LWT Food Sci. Technol., 28(1), 1995, 25-30.

https://doi.org/10.1016/S0023-6438(95)80008-5

33. RE, R., PELlEGRIN, N., PROTEGGENTE, A., PANNAlA, A., YANG, M., RICE-EVANS, C. Antioxidant Activity Applying an Improved ABTS Radical Cation Decolorization Assay, Free Radical Biol. Med., 26(9-10), 1999, 1231-1237. https://doi.org/10.1016/S0891-5849(98)00315-3

34. ARTS, M.J., HAENEN, G.R., VOSS, H.P., BAST, A., Antioxidant Capacity of Reaction Products Limits the Applicability of the Trolox Equivalent Antioxidant Capacity (TEAC) Assay, Food Chem Toxicol., 42(1), 2004, 45-49. https://doi.org/10.1016/j.fct.2003.08.004

35. BENZIE, I.F., STRAIN, J.J., The Ferric Reducing Ability of Plasma (FRAP) as a Measure of "Antioxidant Power": The FRAP Assay, Anal. Biochem., 239(1), 1996, 70-76.

https://doi.org/10.1006/abio.1996.0292

36. MILlER, J.N., MILLER, J.C., Statistics and Chemometrics for Analytical Chemistry, Pearson Education Limited, London, England, 2005, 15

37. Chandran, S., Singh, R.S., Comparison of Various International Guidelines for Analytical Method Validation, Pharmazie, 62(1), 2007, 4-14. DOI: 10.1691/ph2007.1.5064

38. LERMUSIEAU, G., LIEGEOIS, C., COLliN, S., Reducing Power of Hop Cultivars and Beer Ageing, Food Chem., 72(4), 2001, 413-418.

https://doi.org/10.1016/S0308-8146(00)00247-8

39. PROESTOS, C., BOZIARIS, I.S., NYCHAS, G.-J.E., KOMAITIS, M., Analysis of Flavonoids and Phenolic Acids in Greek Aromatic Plants: Investigation of Their Antioxidant Capacity and Antimicrobial Activity, Food Chem., 95(4), 2006, 664-671.

https://doi.org/10.1016/j.foodchem.2005.01.049

40. KOVAČOVA, J., LEHOTAY, J., URGEOVA, E., MOCAK, J., ČIŽMARIK, J., Determination of Selected Flavonoids in Hop Extract by HPLC, J. Liq. Chromatogr. Relat. Technol., 34(5), 2011, 329340. https://doi.org/10.1080/10826076.2011.551596

41. MCMURROUGH, I., HENNIGAN, G.P., LOUGHREY, M.J., Quantitative Analysis of Hop Flavonols Using High-Performance Liquid Chromatography, J. Agric. Food Chem., 30(6), 1982, 11021106. https://doi.org/10.1021/jf00114a024

42. CALLEMIEN, D., JERKOVIĆ, V., ROZENBERG, R., COLLIN S., Hop as an Interesting Source of Resveratrol for Brewers: Optimization of the Extraction and Quantitative Study by Liquid chromatography/atmospheric Pressure Chemical Ionization Tandem Mass Spectrometry, J. Agric. Food Chem., 53(2), 2005, 424-429. https://doi.org/10.1021/jf040179n

43. MAGAlHAES, P.J., VIEIRA, J.S., GONCALVES, L.M., PACHECO, J.G., GUIDO, L.F., BARROS, A.A., Isolation of Phenolic Compounds From Hop Extracts using Polyvinylpolypyrrolidone: Characterization by High-Performance Liquid Chromatography-Diode Array Detection-Electrospray Tandem Mass Spectrometry, J. Chromatogr. A, 1217(19), 2010, 3258-3268. https://doi.org/10.1016/j.chroma.2009.10.068

44. GHISELli, L., TALlARICO, R., ROMAGNOLI, S., DE ACUTIS, L., BENEDETTELLI, S., Antioxidant and Mineral Element Characterization in Spontaneous Hop (Humulus lupulus L.) in Central Italy, Agrochimica, 59(4), 2015, 319-334.

DOI: $10.12871 / 0021857201544$

45. MALANDRINO, M., GIACOMINO, A., ABOllinO, O., AlliO, A., TONIOLO R., COLOMBO, M.L., Determination of Major, Minor and Trace Elements in Glyceric Macerates and Mother Tinctures and in the Starting Plant Material, J. Pharm. Biomed. Anal., 106, 2015, 167-178. https://doi.org/10.1016/j.jpba.2014.10.036

Manuscript received: 24.09.2019 
